\title{
Regional scale analysis of landform configuration with base-level (isobase) maps
}

\author{
C. H. Grohmann, C. Riccomini, and M. A. C. Chamani \\ Institute of Geosciences, University of São Paulo, São Paulo, SP, Brazil \\ Received: 26 November 2010 - Published in Hydrol. Earth Syst. Sci. Discuss.: 10 January 2011 \\ Revised: 4 May 2011 - Accepted: 13 May 2011 - Published: 18 May 2011
}

\begin{abstract}
Base-level maps (or "isobase maps", as originally defined by Filosofov, 1960), express a relationship between valley order and topography. The base-level map can be seen as a "simplified" version of the original topographic surface, from which the "noise" of the low-order stream erosion was removed. This method is able to identify areas with possible tectonic influence even within lithologically uniform domains. Base-level maps have been recently applied in semi-detail scale (e.g., 1:50000 or larger) morphotectonic analysis. In this paper, we present an evaluation of the method's applicability in regional-scale analysis (e.g., 1:250000 or smaller). A test area was selected in northern Brazil, at the lower course of the Araguaia and Tocantins rivers. The drainage network extracted from SRTM30_PLUS DEMs with spatial resolution of approximately $900 \mathrm{~m}$ was visually compared with available topographic maps and considered to be compatible with a 1:1,000 000 scale. Regarding the interpretation of regional-scale morphostructures, the map constructed with 2 nd and 3rd-order valleys was considered to present the best results. Some of the interpreted base-level anomalies correspond to important shear zones and geological contacts present in the 1:5000000 Geological Map of South America. Others have no correspondence with mapped Precambrian structures and are considered to represent younger, probably neotectonic, features. A strong E-W orientation of the base-level lines over the inflexion of the Araguaia and Tocantins rivers, suggest a major drainage capture. A N-S topographic swath profile over the Tocantins and Araguaia rivers reveals a topographic pattern which, allied with seismic data showing a roughly N-S direction of extension in the area, lead us to interpret this lineament as an E-W, southward-dipping normal fault. There is also a good visual correspondence between the base-level lineaments and
\end{abstract}

Correspondence to: C. H. Grohmann (guano@usp.br) geophysical anomalies. A NW-SE lineament in the southeast of the study area partially corresponds to the northern border of the Mosquito lava field, of Jurassic age, and a NW-SE lineament traced in the northeastern sector of the study area can be interpreted as the Picos-Santa Inês lineament, identifiable in geophysical maps but with little expression in hypsometric or topographic maps.

\section{Introduction}

The concept of base level was defined by Powell (1875) as a level "below which the dry lands cannot be eroded". Although the sea level remains the ultimate base level, several authors have acknowledged that local base levels can be defined according to different geological/temporal conditions across regions or even within the same watershed (e.g., Powell, 1875; Davis, 1902; Mackin, 1948; Penck, 1953; Quirk, 1996).

Base-level maps (Dury, 1952; Filosofov, 1960; Pannekoek, 1967) express a relationship between valley order and topography. The valley order refers to the relative position of stream segments in a drainage basin network, where streams of similar orders relate to similar geological events and are of similar geological age (Horton, 1945; Strahler, 1952; Golts and Rosenthal, 1993). Each base-level surface is related to similar erosional stages, and can be considered a product of erosional-tectonic events, mainly the most recent ones (Golts and Rosenthal, 1992, 1993).

The drainage network is a reliable indicator of tectonic activity. It is important to note, however, that stream long profiles are sensitive to other forces than tectonics, such as lithology, climate and bed-load, among others. For instance, a lithologic boundary of two rocks of different erosional properties will results in a change in the channel slope and the local order base-levels will therefore be different even in the absence of deformation. Another example is the case of an

Published by Copernicus Publications on behalf of the European Geosciences Union. 


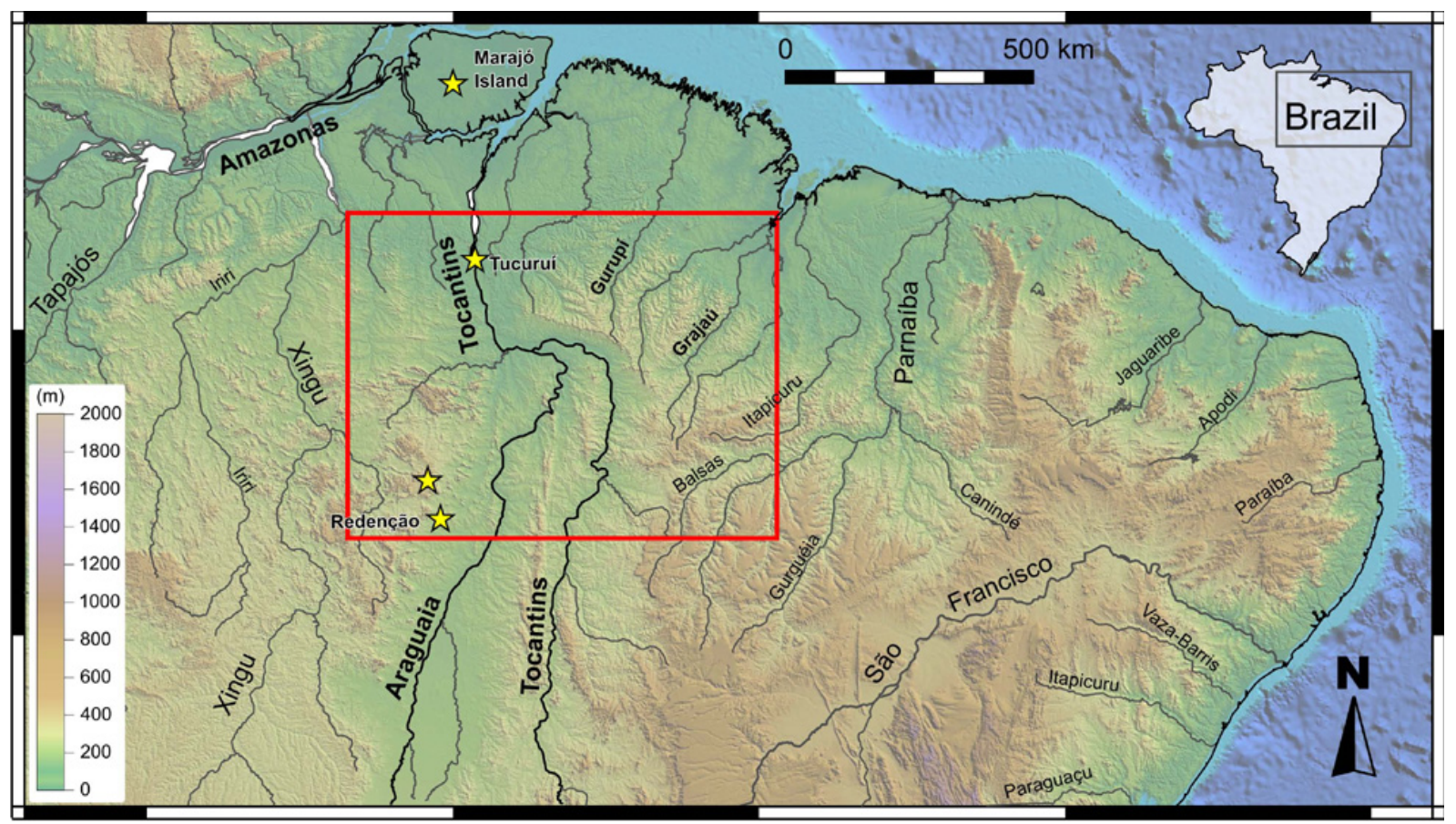

Fig. 1. Location of study area (red rectangle). Stars represent epicenters of earthquakes. See text for details.

uniform rock uplift. If the entire stream network is elevated the relative base-levels that are investigated will show no difference relative to one another. In this case, other channel metrics such as the reference slope (Sklar and Dietrich, 1998), or the channel steepness (Hack, 1973), are capable of recording such strain.

The concept of base-level map, as used in this paper, is the same as the "isobase map" of Filosofov (1960, 1970, 1975) and Golts and Rosenthal $(1992,1993)$, and is similar to the "Thalweg" of Annaheim (1946), the "Reliefsockel" of Louis (1957), the "streamline surface map" of Dury (1952) and Pannekoek (1967), the "subenvelope map" of Hack (1960), or the "Sloping Local Base Level" of Jaboyedoff et al. (2004, 2009). The main goal of this method is to be able to identify areas with possible tectonic influence even within lithologically uniform domains.

Base-level maps have been recently applied in semidetail scale (e.g., 1:50 000 or larger) morphotectonic analysis (Golts and Rosenthal, 1993; Modenesi-Gauttieri et al., 2002; Grohmann et al., 2007; Jaboyedoff et al., 2009). Filosofov (1960) recommended to use 1:100 000 topographic maps with $20 \mathrm{~m}$ contours for flat terrains and 1:50000 or less for "poor"-manifested topography or poor topographic maps. This author also recommended to use 1:1000000 topographic maps to reveal a general tectonic composition of large territories. Moreover, the Filosofov method has been used by former-USSR petroleum geologists for about $30 \mathrm{yr}$, who have observed and reported correlations between base- level and gravity maps (I. Florinsky, personal communication, 11 January 2011).

In this paper, we present an evaluation of the method's applicability in regional-scale analysis (e.g., 1:250000 or smaller). A test area was selected in northern Brazil, at the lower course of the Araguaia and Tocantins rivers (Fig. 1). Also, a comparison with available geological maps and geophysical (gravimetric and magnetometric) data is presented.

\section{Study area}

The Parnaíba Sedimentary province, as defined by Goés (1995) encompasses three sedimentary basins, with distinct ages and origins: the Parnaíba Basin (Silurian-Triassic), the Alpercatas Basin (Jurassic-Cretaceous) and the Grajaú Basin (Cretaceous). The basement of the Parnaíba Sedimentary Province in the study area are igneous and high- to low grade metamorphic rocks of the Amazonian Craton and Araguaia Belt, with ages ranging from Archean to Neproterozoic (Schobbenhaus et al., 1984). Structures in the precambrian basement had a great influence in the installation and development of the sedimentary basins of the Parnaíba Sedimentary Province, the main ones in the study area being the Tocantins-Araguaia Lineament, the Picos-Santa Inês Lineament, the Xambioá Arch and the Rio Grajaú Lineament.

The N-S-oriented Tocantins-Araguaia Lineament (Kegel, 1965) follows the N-S-trending Precambrian structural grain of the Araguaia Belt and represents the western border of 
the Parnaíba Basin, which was installed in the Silurian. NS-trending structures also influenced the Permian sedimentation in the Parnaíba Basin and were the sites of basaltic magmatic activity during Triassic and Jurassic times (Cordani et al., 1984). The NW-SE-oriented Picos-Santa Inês Lineament probably corresponds to a shear zone and is marked in the study area by an alternance of positive and negative Bouger anomalies (Cunha, 1986) probably associated with intrusive Mesozoic basic rocks.

Along the E-W-oriented Xambioá Arch more than $1000 \mathrm{~m}$ of Late Carboniferous to Middle Triassic deposits of the Balsas Group were accumulated (Goés, 1995), the structure representing a probable rift basin at that time-interval. Other E-W-trending structures delimit the Alpercatas Basin and the area of occurrence of the Jurassic volcanic rocks of the Mosquito Formation (CPRM, 2004). In the Early Cretaceous, the Xambioá Arch was uplifted, acting as a divide between the Grajaú Basin, to the north, and the Espigão-Mestre Basin, to the south (outside of the study area). The depositional axis of the Grajaú Basin is parallel to the Rio Grajaú Lineament (Goés, 1995).

To the north of the study area, Costa et al. (2001) considers that the neotectonic evolution is marked by two sets of structures, NW-trending normal faults which control the deposition of Late Tertiary deposits, and E-W trendind rightlateral strike-slip faults controlling the deposition of LatePleistocene to Holocene alluvial deposits. In this context, $\mathrm{N}-\mathrm{S}$ oriented structures (the Tocantins-Araguaia and parallel faults) behave as reverse faults whereas the NW-oriented structures (as the Picos-Santa-Inês Lineament) behave as normal faults. It is worth to note that a few seismic events were recorded in the study area (epicenters are marked by yellow stars in Fig. 1). Around the town of Redenção two events with $m_{b} 4.7$ and 4.2 occurred in December 1980 and November 2010, respectively, the first with a normal-fault focal mechanism and a general N-S direction of extension (Assumpção et al., 1985). A set of induced earthquakes occurred between November 1985 and March 1988 after the impoundment of the Tucuruí reservoir, the larger with $\mathrm{m}_{\mathrm{b}}$ 3.6, but no focal mechanisms were obtained for these events (Assumpção et al., 2001). The epicenters are concentrated around the dam and roughly distributed along a N-Strending Precambrian reverse fault (Tocantins-Araguaia Lineament). Farther North, in the Marajó Island (Amazon River mouth), a $m_{b} 4.8$ earthquake with a NNW-SSE direction of extension and an ENE-SSW direction of compression was recorded on August 1977 (Assumpção et al., 1985). These data indicate a present-day, roughly N-S direction of extension in the region.

It is worth noting that until the mid-1990's, the concept of neotectonics was new to Brazilian geologists, and the continental shield was considered to be stable (Riccomini and Assumpção, 1999). The geological mapping of the whole country carried out at a 1:1000000 scale during the 1970's and 1980's (Radambrasil Project) payed more attention to

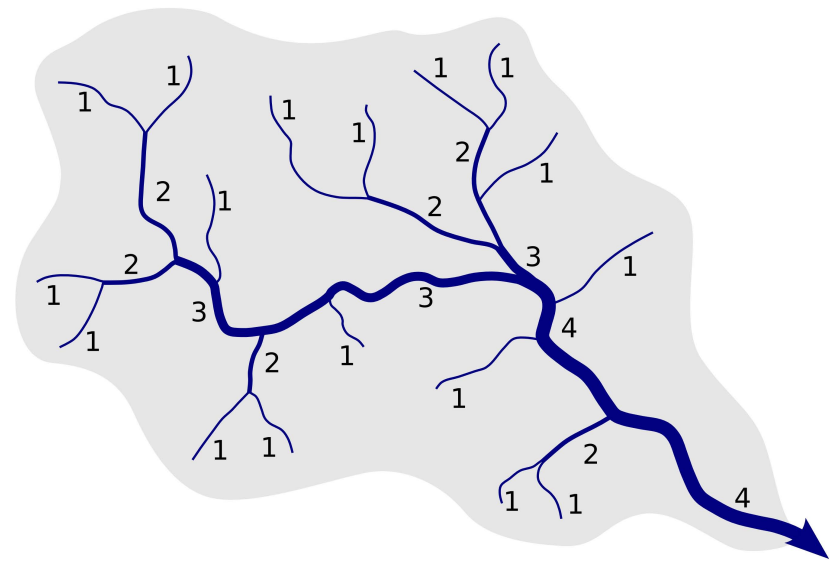

Fig. 2. Stream ordering in a watershed, according to Strahler (1952). Streams without tributaries are assigned first order; a second-order stream is the segment downstream the confluence of any two first-order streams; a third-order segment is formed by the junction of any two second-order streams and so on. Modified from FISRWG (1998).

Precambrian shear zones, and did not considered much the younger brittle structures in its maps. Thus, a lineament or structure interpreted on a morphostructural map that does not have a correspondence with a Precambrian shear zone is likely to be of neotectonic origin.

\section{Base-level maps}

Given that in Earth Sciences the term "isobase" is used in the sense of a "line of equal uplift" and is commonly applied to marine terraces and shorelines raised in the Holocene (e.g., Leverington et al., 2002), we think that "base-level map" should be used instead of "isobase map" in morphotectonic studies, even though the latter has been used recently in this sense (e.g., Golts and Rosenthal, 1993; Grohmann et al., 2007).

\subsection{Construction and interpretation}

Base-level maps are constructed from an initial map of valley orders, classified according to the Strahler (1952) system, which is based on the number of tributaries upstream of a valley segment. Streams without tributaries are assigned first order (headwater streams). A second-order stream is the segment downstream the confluence of any two first-order streams and a third-order segment is formed by the junction of any two second-order streams and so on (Fig. 2).

The points where individual thalwegs are crossed by contours of the same elevation are connected by smooth lines (isobases). These lines should cross the thalwegs at right angles and are plotted in a similar manner of topographic contours (Zuchiewicz, 1989) (Fig. 3). Several base-level maps 
a) Original contours and drainage network

b) Classification of drainages and selection of $2^{\text {nd }}$ and $3^{\text {rd }}$ order channels

c) Intersections of contours with selected stream orders

d) Interpolation of base-level surface from elevation of intersection points

e) Interpretation of fault from abrupt change in base-level isoline orientation
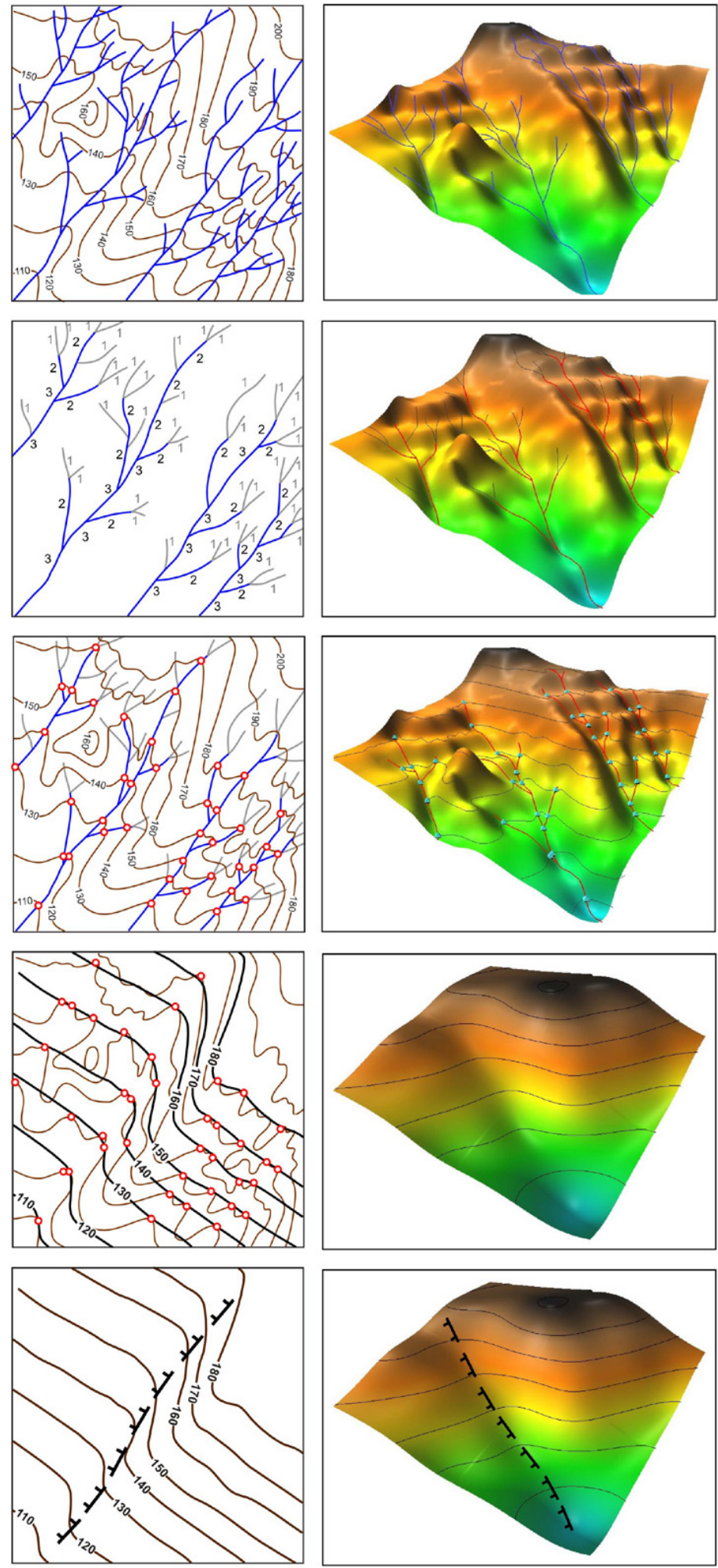

Fig. 3. Development of a 2nd-order base-level map. (a) Original topography (contours) and drainage network. (b) Classification of drainage network and selection of 2nd and 3rd-order channels. In this case,1st-order streams are discarded. (c) Determination of intersection points of contours and selected stream channels. Elevation of contour is assigned to each point. (d) Interpolation of base-level lines (or surface) from elevation of intersection points. (e) Fault traced according to deviations of base-level lines. Modified from Golts and Rosenthal (1993). 

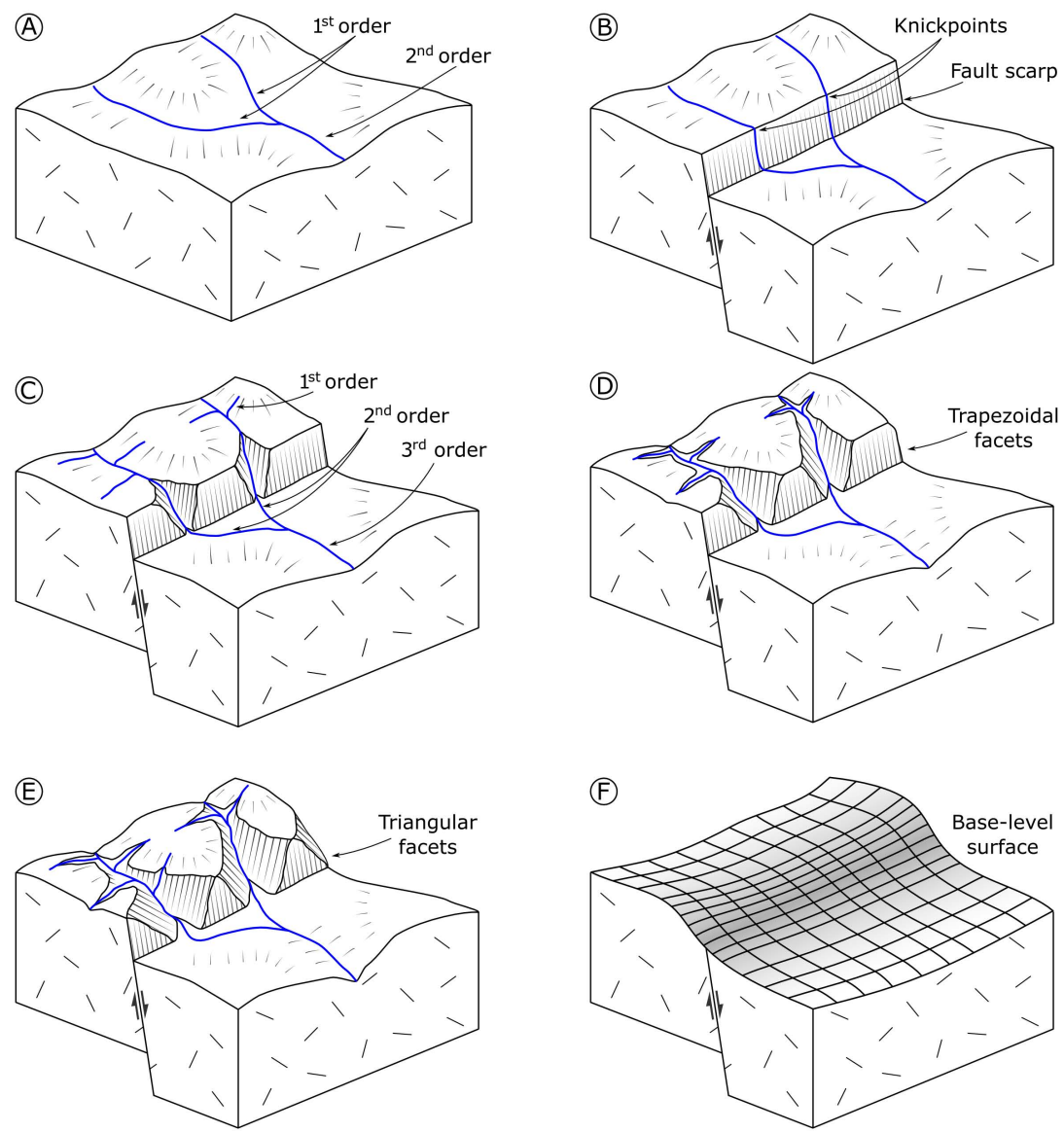

Fig. 4. Schematic evolution of a normal fault scarp, with development of knickpoints and new 1st-order streams. The scarp will be segmented into a series of trapezoidal facets, which will became triangular and will be progressively eroded, until the original morphology cannot be recognized. A base-level map, constructed from the elevations of 2 nd and 3rd-order channels, shows an inflexion in the faultline area.

can be made for a given region. For instance, in the 2ndorder base-level map, all valleys except those of 1st-order will be used for plotting. The 3rd-order base-level map is constructed from all valleys except those of 1 st- and 2 ndorder, and so on. The base-level map can be seen as a simplified form of the original topography, where the relief above the base-level surface is disregarded.

Manual production of base-level maps is a timeconsuming process. Classification of valley orders and interpretation of base-level lines demands topographic maps of good quality and in a proper scale. Using digital elevation models (DEMs) for automatic extraction and classification of stream channels allows the data for a large area to be obtained faster and usually at no cost (Grohmann et al., 2007). Shuttle Radar Topography Mission (SRTM - Farr et al., 2007) DEMs have a spatial resolution of $0^{\circ} 0^{\prime} 03^{\prime \prime}(\sim 90 \mathrm{~m}$ at the Equator), which can be approximated to a 1:100 000 scale. For regional-scale analysis, one can use SRTM30_PLUS V3 DEMs (Becker and Sandwell, 2007), a global dataset with spatial resolution of $0^{\circ} 0^{\prime} 30^{\prime \prime}(\sim 900 \mathrm{~m}$ at the Equator). It should be noted that stream classification depends on the resolution of the DEM, that is, with higher spatial resolutions the drainage network will tend to be denser, with more loworder streams than with a lower resolution, so trunk rivers are more likely to present a higher Strahler order.

Construction of base-level maps in a GIS environment is fairly simple. From a DEM of the area of interest, one can derive the drainage network using several available algorithms, depending on the characteristics of the landscape and the spatial resolution of the data source (e.g., Tarboton and Bras, 1991; Orlandini et al., 2003; Grimaldi et al., 2007, 2010; Nardi et al., 2008). This drainage can be classified and the elevation points used to interpolate the base-level surface can be extracted by overlaying the desired stream orders with contours derived from the DEM. Using contours as a source for elevation (resembling the manual method) instead of using all the elevation values along the stream lines might sound as an unnecessary complication, but our experience shows it provides better results. As with any interpolation procedure, one must avoid clusters of data points 

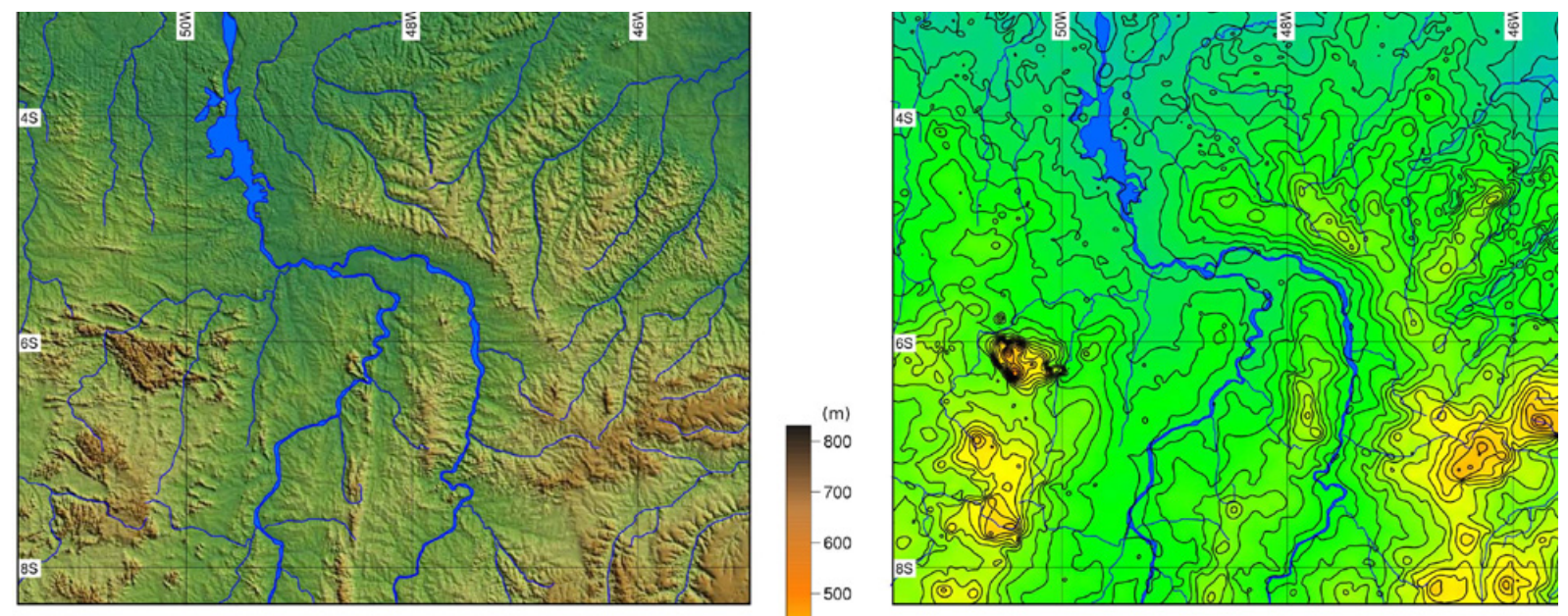

C) $3^{\text {rd }}+4^{\text {th }}$ order

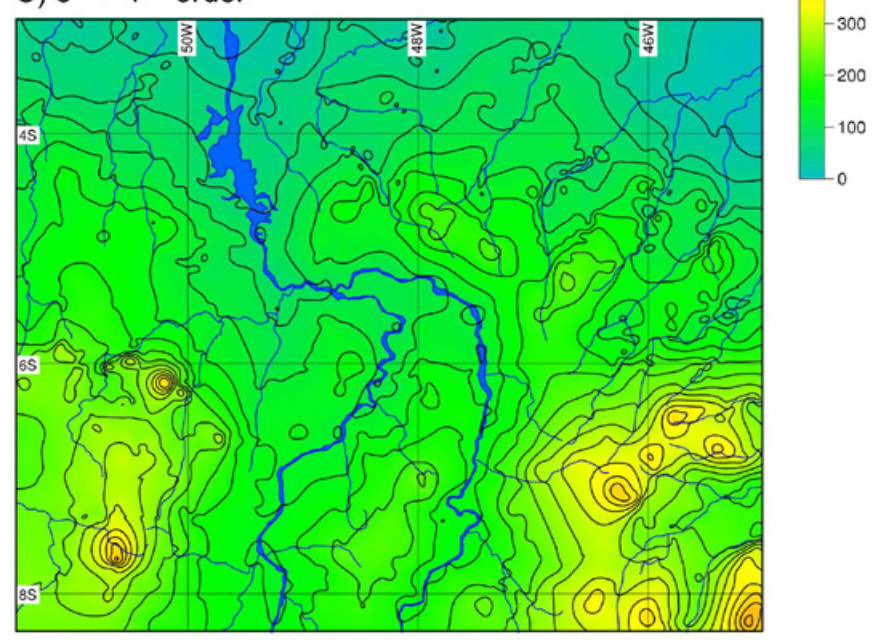

D) $4^{\text {th }}+5^{\text {th }}$ order

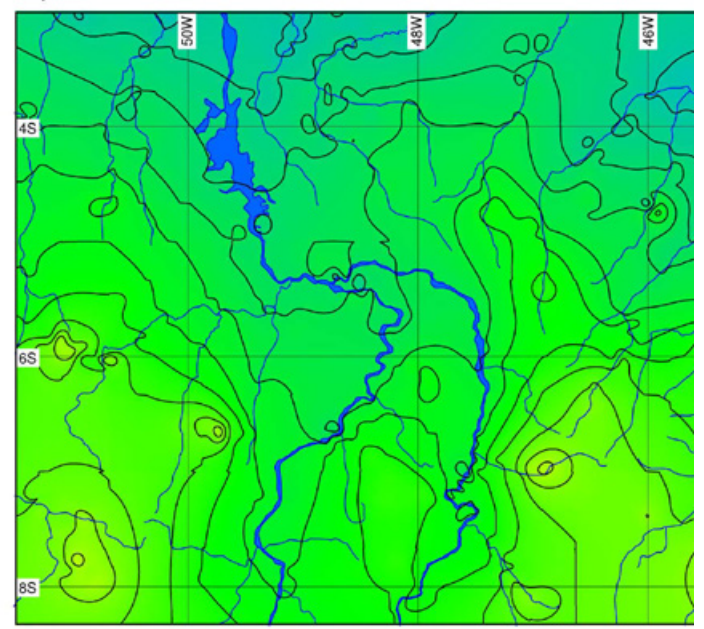

Fig. 5. (a) Colored shaded relief image of the study area (illuminant at N045, $30^{\circ}$ above horizon). (b-c-d) Base-level maps constructed for the study area. See text for details.

and use, whenever possible, points with a uniform distribution over the target area in order to prevent interpolation artifacts (Chaplot et al., 2006; Berry, 1997; Yilmaz, 2007; Yue et al., 2007). Extracting the elevation from the intersection of streams and contours yields a smaller number of points to be interpolated, without clusters along streams.

Disregarding 1st-order streams intends to eliminate the "noise" that could prevent the identification of a scarp or other significant feature of the topographic surface. As an example, Fig. 4 presents a schematic scenario for the geomorphological evolution of a normal fault scarp. The initial condition (Fig. 4a) is disturbed by a fault and knickpoints indicate the break-of-relief (Fig. 4b). As erosion progresses, new 1st-order streams appear and a segmentation of the the fault scarp into trapezoidal facets can be observed (Fig. 4cd). These facets will evolve into triangular forms (Fig. 4e) and will eventually be suppressed, when the clear identifica- tion of the fault may be hard or impossible. A time span of about $10^{5} \mathrm{yr}$ would be sufficient to degrade a fresh fault scarp to a point where all remnants of the tectonic surface were removed (Stewart and Hancock, 1990). A base-level map, constructed from the elevations of 2 nd and 3rd-order channels, although smoother and simpler than the original topography, would show an inflexion in the faultine area (Fig. 4f).

Interpretation of base-level maps and identification of base-level lineaments is not an exact science, and experience plays an important role here. One must look for patterns in the base-level isolines, such as aligned and elongated features, compression or spreading and sharp deviations in contours which can be indicative of structures associated to tectonic movements, extreme lithological changes or important geomorphological features. Working with contours overlaid over the base-level surface map is easier than working only with a colored or greyscale map. Relief shading might be 
very useful, but one must consider the effects of illumination over linear terrain features (Grohmann, 2004; Smith and Wise, 2007). In the example of Fig. 4, the inflexion is marked by a compression of base-level lines, while in Fig. 3 the baselevel anomaly is given by the abrupt deviation of contours. These areas would be interpreted as the most probable targets for field investigation and possible confirmation of structures whose recent tectonic activity left signals in landscape.

Therefore, results from a base-level map interpretation should be taken as qualitative (not quantitative) in the sense that they will not predict the exact location of tectonic structures, but would be used to guide and plan in situ investigations. It is particularly useful to optimize an otherwise costly, time-consuming field survey in large, heavily vegetated areas of poor accessibility, such as the study area.

\subsection{Previous applications}

In this section, some applications of base-level maps ("isobase maps" of Filosofov, 1960) in morphotectonic studies are presented.

Golts and Rosenthal (1993) derived a morphotectonic map from base-level lines for an area of approximately $1100 \mathrm{~km}^{2}$ in northern Arava, a part of the Jordan-Dead Sea Rift Valley. They conclude that in young sedimentary basins characterized by flat and weakly incised relief, the base-level map was useful as structural background for designing detailed investigations, such as seismic surveys.

The influence of the geological structure on the geomorphology of an area of the Basin and Range Province (NE Utah, USA) was analysed by Zuchiewicz and Oaks (1993). From topographic data at 1:100000 scale, base-level maps of 1st-, 2nd- and 3rd-order were made. The maps of 1st- and 2nd-order were considered to closely resemble the original topography, but the map of 3rd-order showed the dominant faults and folds undulations.

Sant'Anna et al. (1997) studied the Cenozoic tectonics of the Fonseca Basin region, in the Quadrilátero Ferrífero (southeastern Brazil). The morphostructural map confirmed the existence of major tectonic discontinuities with N-S and, less frequently, E-W, NE and NW directions. The same area was studied by Grohmann (2004), who compared manually created base-level maps with automatic processing of digital elevation data in a GIS environment and concluded that both products were similar.

The morphotectonic analysis of a high plateau on the northwestern flank of the Continental Rift of southeastern Brazil showed that fault reactivation along Precambrian shear zones was responsible for drainage captures and segmentation of the plateau into smaller blocks, which could be identified in the 2nd-order base-level map (Hiruma and Riccomini, 1999; Modenesi-Gauttieri et al., 2002).

Ribeiro et al. (2006) applied base-level maps in a morphotectonic analysis of an area at the top of the Serra do Mar
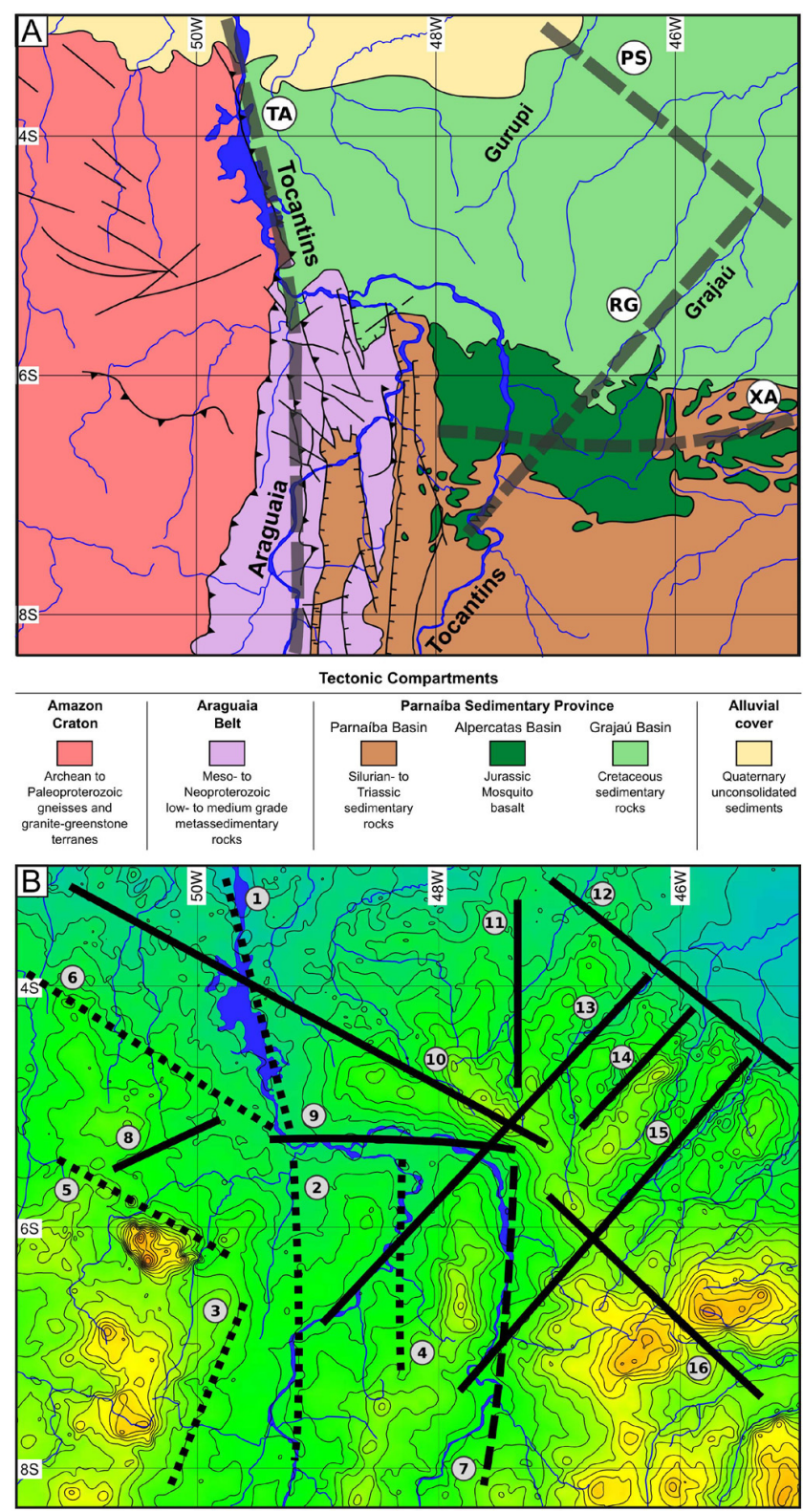

Fig. 6. (a) Simplified geological map of the area (Modified from Schobbenhaus and Bellizzia, 2001). TA: Tocantins-Araguaia Lineament. PS: Picos-Santa Inês Lineament. RG: Rio Grajaú Lineament. XA: Xambioá Arch. (b) Interpreted structures for the baselevel map constructed with 2 nd and 3 rd valley orders. See text for details.

coastal range of the State of São Paulo, Brazil. A 2nd-order base-level map was manually created from 1:10000 topographic maps and showed that the drainage of the Guaratuba river basin is controlled by NW-trending faults, which were responsible for drainage capture and subsequent isolation of this sub-basin from the upper Tietê river. Since the fish species occurring in the upper Guaratuba river are identical 


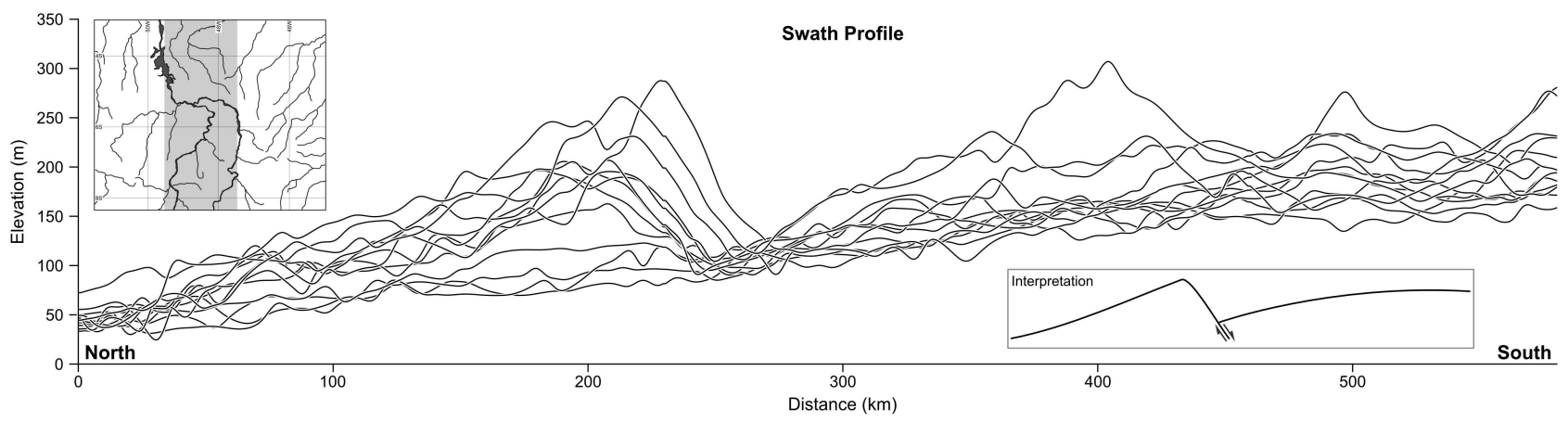

Fig. 7. N-S swath profile of 2nd-order base-level map (Fig. 5b). Swath location is the gray area in upper left inset. Lower right inset shows an interpretation as a southward-dipping normal fault.

to the ones that occur in the upper Tietê river, the river piracy event is of young geological age and was inferred to be of Late Pleistocene-Holocene.

The Pocos de Caldas Alkaline Massif is a $33 \mathrm{~km}$-diameter Late Cretaceous collapsed volcanic caldera located in southeastern Brazil. The massif's main morphology is a semicircular plateau with average altitude of $1300 \mathrm{~m}$ rising up to $400 \mathrm{~m}$ above surrounding flatlands (Pocoss de Caldas Plateau), with elevations up to $1500-1600 \mathrm{~m}$ at its borders. A 2nd-order base-level map of the massif showed a partial coincidence of a lithologic change in the northeastern portion of the massif with a strong NE-SW base-level anomaly, which turns abruptly to NW-SE in the central area of the plateau, without any associated variation in lithology. The large NE-SW anomaly was related by Grohmann et al. (2007) to a faultline previously identified by Almeida Filho and Paradella (1977) while the NW-SE smaller anomaly was considered a result of recent tectonic activity.

The Sloping Local Base Level (SLBL) of Jaboyedoff et al. (2004) is a generalization of the base level concept applied to landslides. It is very similar to the original isobase surface of Filosofov (1960) and allows the definition of a surface above which a rock mass is assumed erodible. Jaboyedoff et al. (2009) used the SLBL method to estimate the present unstable volumes in the main scar of a $30 \mathrm{M} \mathrm{m}^{3}$-rockslide in the eastern slope of Turtle Mountain (Alberta).

\section{Methods}

All data processing was carried out with GRASS-GIS version 6.4 (Neteler and Mitasova, 2008; GRASS Development Team, 2009). As topographic base, we used SRTM30_PLUS V3 DEMs (Becker and Sandwell, 2007), with spatial resolution of $0^{\circ} 0^{\prime} 30^{\prime \prime}(\sim 900 \mathrm{~m})$. Drainages were extracted using an $\mathrm{A}^{\mathrm{T}}$ least-cost search algorithm designed to minimize the impact of DEM data errors (Ehlschlaeger, 1989).
This algorithm provides more accurate results in areas of low slope and also on DEMs where canopy top might be mistaken as ground elevation, such as SRTM (Kinner et al., 2005). Water flow was calculated using a multiple flow direction (MFD) method, where the water flow is distributed to all neighboring cells with lower elevation using slope towards these cells as a weighing factor for proportional distribution, a convergence factor of 5 as recommended by Holmgren (1994) and a minimum size of an exterior watershed basin of 25 cells $\left(\sim 640 \mathrm{~km}^{2}\right)$. The extracted drainage network was visually compared with available topographic maps and was considered to be compatible with a 1:1000000 scale.

The base-level maps were constructed with an adaptation of the methods proposed by Grohmann (2004). First, the drainage network in raster format was classified according to Strahler's system and converted to a vector format. The elevation of intersection points between drainage and contours (derived from the DEM) was used to create $3-\mathrm{D}$ vector points and interpolated into a continuous surface with Regularized Splines with Tension (RST - Mitasova and Mitas, 1993; Mitas and Mitasova, 1999; Hofierka et al., 2002). Base-level maps were constructed according to the following valley orders combinations: 2 nd $+3 \mathrm{rd}$, $3 \mathrm{rd}+4$ th, 4 th +5 th. The resulting maps are presented in Fig. 5.

\section{Results and discussion}

Regarding the interpretation of regional-scale morphostructures, the map constructed with 2 nd and 3rd-order valleys (Fig. 5b) was considered to present the best results. In the map of 3rd and 4th orders (Fig. 5c), the large structures still can be identified, although with less detail. The map of 4th and 5th orders (Fig. 5d) is oversimplified and does not provide useful information.

A simplified geological map of the area is shown in (Fig. 6a, and the interpreted base-level anomalies are presented in Fig. 6b. In Fig. 6b, lineaments numbered from \#1 to \#6 correspond to Pre-Paleozoic faults or with geological 

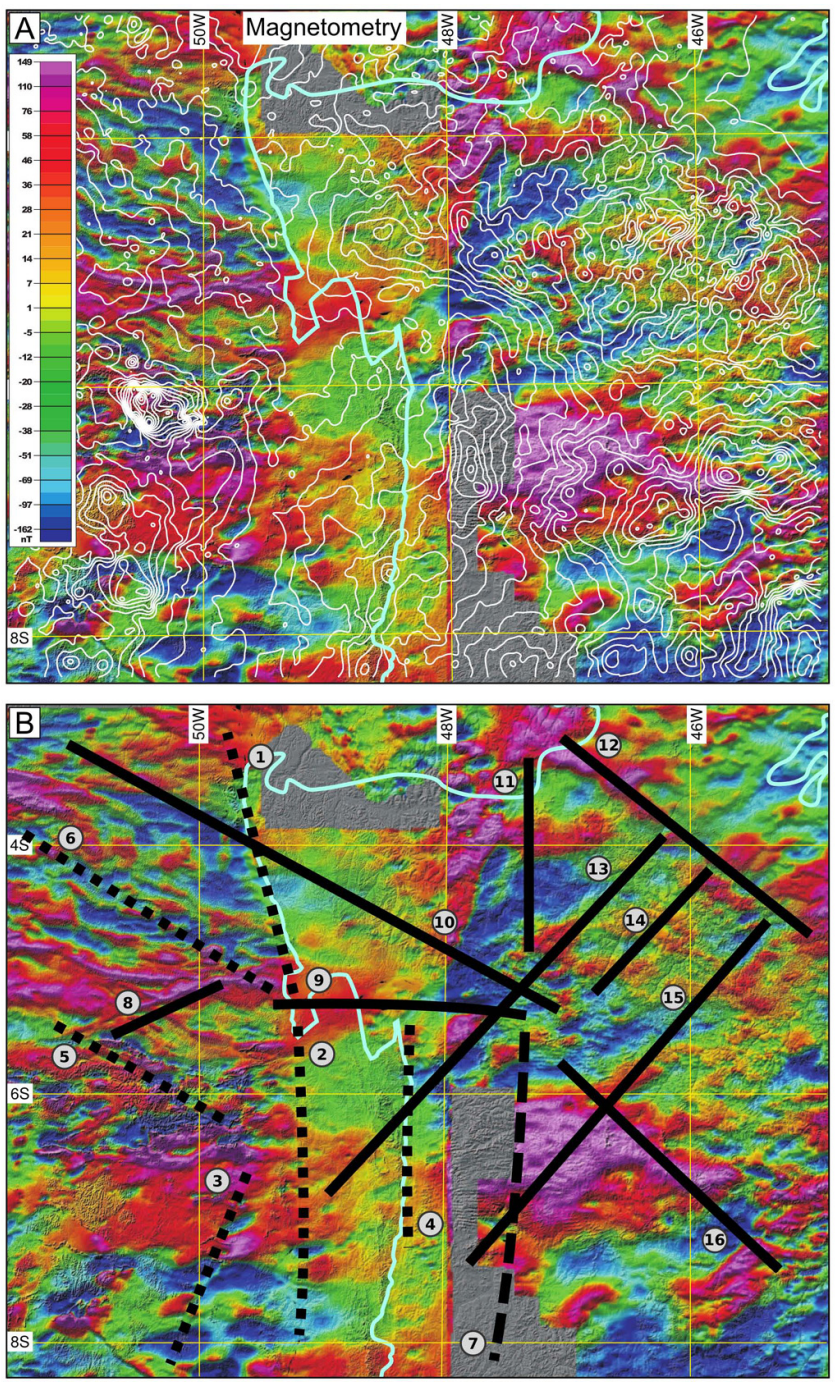

Fig. 8. Magnetic total field intensity anomaly (IGRF corrected), $1 \mathrm{x} 1 \mathrm{~km}$ grid (CPRM, 2004). (a) Contours for base-level map constructed with 2nd and 3rd valley orders. (b) Structures interpreted from base-level map. The cyan solid line represents the limits of the Parnaíba Sedimentary Province. See text for details.

contacts present in the 1:5000000 Geological Map of South America (Schobbenhaus and Bellizzia, 2001); lineament \#7 is related with the present-day valley of Tocantins river and lineaments \#8 to \#16 do not have a clear correspondence with the geological map.

Although none of these mapped structures have ever been connected to recent tectonic events, we must note that some of them, such as the NNW-SSE-trending thrust north of the rivers major inflexion (\#1 in Fig. 6b), correspond to the physical limits of the Parnaíba Sedimentary Province. Therefore, we cannot rule out the possibility that these structures were active during or after the sedimentation of these rocks.
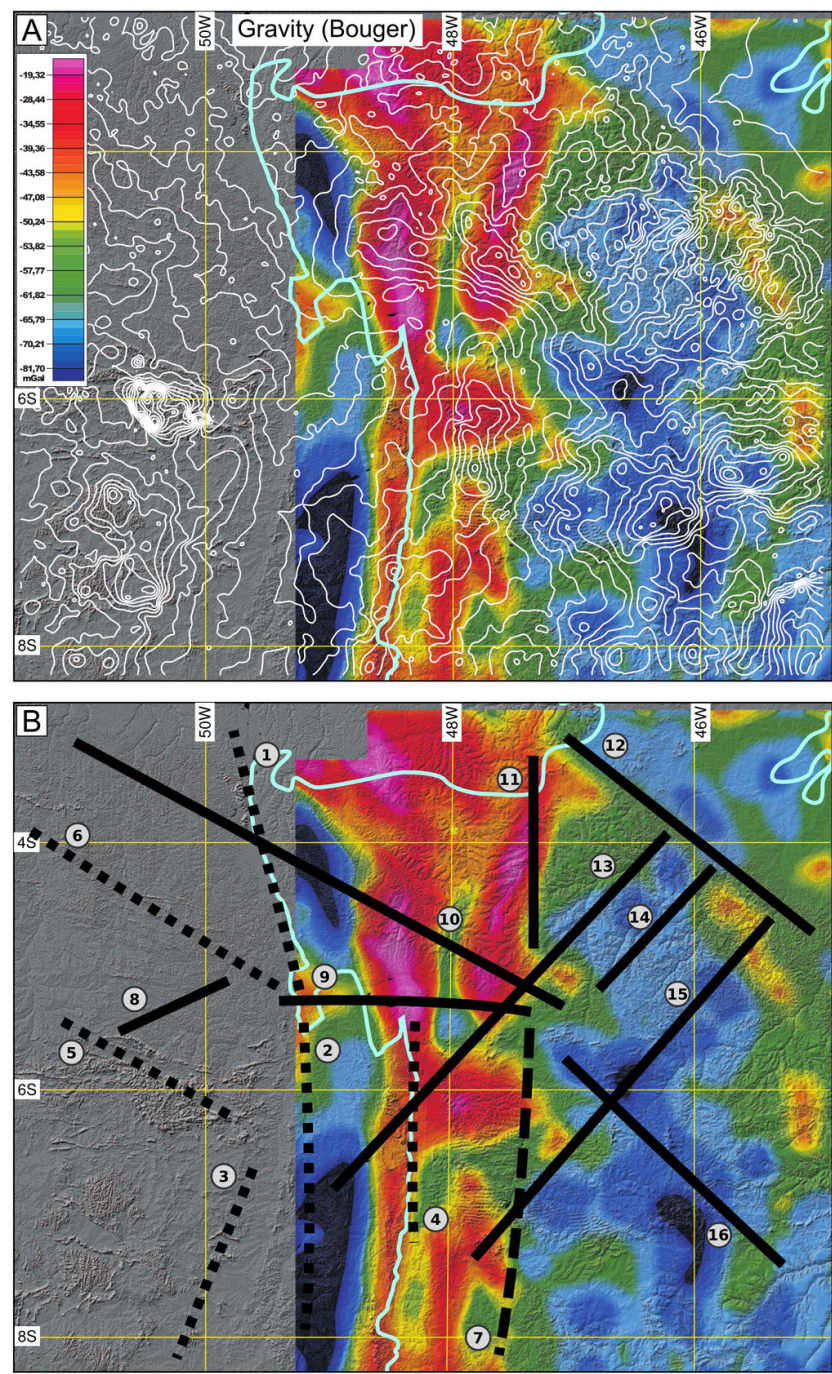

Fig. 9. Gravimetric Bouger anomalies (Redrawn from Petersohn, 2007). (a) Contours for base-level map constructed with 2 nd and 3rd valley orders. (b) Structures interpreted from base-level map. The cyan solid line represents the limits of the Parnaíba Sedimentary Province. See text for details.

A strong E-W orientation of the base-level lines over the inflexion of the Araguaia and Tocantins rivers (\#9 in Fig. 6b), previously identified by Costa et al. (1996) as a right-lateral transcurrent fault zone, suggest a major drainage capture. The Tocantins river flows in a North-Northeast path before this sudden inflexion, and it would seem more natural for it to continue in its lower course towards the sea following the Gurupí river valley, which also has a NNE-SSW orientation (see Figs. 1 and 6a).

Topographic swath profiles (or projected profiles, Baulig, 1926; Tricart and Cailleux, 1957) are those were intersections of contours with equally spaced profile lines are marked within a swath, or band. This kind of profile can provide a 
broader view of altimetric behavior, and help to determine inclination of large topographic features (Meis et al., 1982). Figure 7 shows a N-S swath profile constructed in a band of $2^{\circ}$ with a $10^{\prime}$ interval between individual profiles. There is a general trend of decreasing elevation towards north, which is interrupted about halfway along the profile by a strong increase in elevation and subsequent gradual decrease.

The general topographic pattern admits different interpretations: a southward-dipping normal fault; a northward dipping low-angle reverse fault or even an anticline growth in the northern portion of the profile. The reverse fault interpretation is unlikely since the elevated area in the central sector of the profile would have to be an abnormally-large preserved relief in the hanging wall. A compressive style of deformation is not expected in the intracratonic extensional regime of the Grajaú Basin. Therefore, the most likely interpretation for this structure is an E-W-oriented southward-dipping normal fault (lower right inset in Fig. 7), which allows a best fit to the observed boundary between the Grajaú Basin and the Araguaia Belt. This scenario would imply in a N-S direction of extension, which is in accordance with available seismic data (Assumpção et al., 1985). Given that the abrupt change of elevation in the swath profile corresponds to the E-W inflexion of the Tocantins river, this adds to the hypothesis of a major drainage capture in the lower Tocantins and of tectonic influence in the landform configuration of the study area.

In Figs. 8 and 9, the base-level lines and interpreted structures are overlaid over geophysical data available for the study area (the cyan solid line represents the limits of the Parnaíba Sedimentary Province). Figure 8 shows the magnetic total field intensity anomaly corrected from IGRF in a $1 \times 1 \mathrm{~km}$ grid (CPRM, 2004), and Fig. 9 shows gravimetric Bouger anomalies (Petersohn, 2007). In both cases there is a good visual correspondence between the base-level lineaments and geophysical anomalies (such as alignments of high or low values, or sudden changes in values). Both the NE-SW (lineaments \#8,\#13, \#14, \#15 in Fig. 8b) and NW-SE (lineaments \#5,\#6, \#10, \#12, \#16 in Fig. 8b) trends are easily identified in the magnetic data and some of these structures correspond to sharp changes in gravimetric values (lineaments \#12,\#13 in Fig. 9b).

The NW-SE lineament in the southeast of the study area (\#16 in Figs. 6b, 8b and 9b) partially corresponds to the northern border of the Mosquito lava field, of Jurassic age (Marzoli et al., 1999), and the NW-SE lineament traced in the northeastern sector of the study area (\#12 in Fig. 6b, 8b and 9b) can be interpreted as the Picos-Santa Inês lineament (Cunha, 1986), identifiable in geophysical maps but with little expression in hypsometric or topographic maps (Fig. 5a).

\section{Conclusions}

Base-level analysis has been successfully applied to semidetail scale morphotectonic studies in the past. In this paper we presented an example of the applicability of the method to regional-scale investigations. The base-level map constructed with 2nd and 3rd-order valleys was considered to present the best results and was used for the interpretation of regional-scale morphostructures. The method provided results consistent with the scale of the data used as topographic base and with the drainage network (1:1000 000). Some of the base-level anomalies interpreted correspond to important Precambrian shear zones and geological contacts present in the 1:5000000 Geological Map of South America. Others have no correspondence with mapped structures and are considered to represent younger, probably neotectonic, features. The E-W inflexion of the lower Tocantins is considered as a major drainage capture, originated by an E-W, southwarddipping normal fault. The structures interpreted from the base-level map also presented a good visual correlation with anomalies in geophysical data, allowing the identification of structures with little expression in topographic maps.

Acknowledgements. This study was supported by the State of São Paulo Research Foundation Grants FAPESP 04/06260-5 and 09/17675-5 to Carlos Grohmann. Claudio Riccomini is a Research Fellow of the National Council of Scientific and Technological Development, CNPq Grants 304649/2005-8 and 307871/2010-0. Marlei Chamani has a MSc scholarship from CNPq. The authors are grateful for the comments, criticism and suggestions of S. Castelltort, I. Florinsky, J.-D. Champagnac, S. Grimaldi, M. Jaboyedoff and three anonymous referees, which helped to greatly improve the quality of the paper.

Edited by: P. Molnar

\section{References}

Almeida Filho, R. and Paradella, W. R.: Estudo do Maciço Alcalino de Poços de Caldas através de imagens Landsat com ênfase em mineralizações radioativas, Tech. rep., INPE (11/2-TPT/065), 1977.

Annaheim, H.: Studien zur Geomorphogenese der Südalpen zwischen St. Gotthard und Alpenrand, Geographica Helvetica, 1, 65149, 1946.

Assumpção, M., Suárez, G., and Veloso, J. A.: Fault plane solutions of intraplate earthquakes in Brazil: some constraints on the regional stress field, Tectonophysics, 113, 283-293, 1985.

Assumpção, M., Marza, V., Barros, L., Chimpliganond, C., Soares, J. E., Carvalho, J., Caixeta, D., Amorim, A., and Cabral, E.: Reservoir-induced seismicity in Brazil, Pure Appl. Geophys., 159, 597-617, 2001.

Baulig, H.: Sur une méthode d'analyse altimétrique appliquée à la Bretagne, Bulletin de l'Association de Geographie Francaise, 10, 7-9, 1926.

Becker, J. J. and Sandwell, D. T.: SRTM30_PLUS: Data fusion of SRTM land topography with measured and estimated seafloor topography (Version 3.0), http://topex.ucsd.edu/WWW html/srtm30_plus.html, last access: 9 April 2008, 2007.

Berry, J. K.: Justifiable interpolation, GIS World, 10, 2:34, 1997.

Chaplot, V., Darboux, F., Bourennane, H., Leguédois, S., Silvera, N., and Phachomphom, K.: Accuracy of interpolation techniques 
for the derivation of digital elevation models in relation to landform types and data density, Geomorphology, 77(1-2), 126-141, 2006.

Cordani, U. G., Brito Neves, B. B., Fuck, R. A., Porto, R., ThomazFilho, A., and Cunha, F. M. B.: Estudo preliminar de integração do Pré-Cambriano com os eventos tectônicos das bacias sedimentares brasileiras, Ciência-Técnica-Petróleo, 15, 1-70, 1984.

Costa, J. B. S., Bemerguy, R. L., Hasui, Y., Borges, M. S., Ferreira Jr., C. R. P., Bezerra, P. E. L., Costa, M. L., and Fernandes, J. M. G.: Neotectônica da região Amazônica: aspectos tectônicos, geomorfológicos e deposicionais, Geonomos, 4, 23-44, 1996.

Costa, J. B. S., Memerguy, R. L., Hasui, Y., and Borges, M. S.: Tectonics and paleogeography along the Amazon river, J. S. Am. Earth Sci., 14, 335-347, doi:10.1016/S0895-9811(01)00025-6, 2001.

CPRM: Geological Survey of Brazil - The Geological Map of Brazil - Scale 1:1 000 000, Magnetic Total Field Intensity Anomaly (IGRF corrected), $1 \times 1 \mathrm{~km}$ grid, 2004 .

Cunha, F. M. B.: Evolução paleozóica da Bacia do Parnaíba e seu arcabouo tectônico, Master's thesis, Instituto de Geociências, Universidade Federal do Rio de Janeiro, Rio de Janeiro, 1986.

Davis, W. M.: Baselevel, grade and peneplain, J. Geol., 10, 77-111, 1902.

Dury, G. H.: Map interpretation, Arnold, London, 1952.

Ehlschlaeger, C. R.: Using the $\mathrm{A}^{\mathrm{T}}$ Search Algorithm to Develop Hydrologic Models from Digital Elevation Data, in: International Geographic Information Systems (IGIS) Symposium '89, Baltimore, Proceedings, 275-281, 1989.

Farr, T. G., Rosen, P. A., Caro, E., Crippen, R., Duren, R., Hensley, S., Kobrick, M., Paller, M., Rodriguez, E., Roth, L., Seal, D., Shaffer, S., Shimada, J., Umland, J., Werner, M., Oskin, M., Burbank, D., and Alsdorf, D.: The Shuttle Radar Topography Mission, Review of Geophysics, 45, RG2004, doi:10.1029/2005RG000183, 2007.

Filosofov, V. P.: Brief guide to morphometric methods in search of tectonic structures, Saratov, Saratov Univ. Publ. House., 1960 (in Russian).

Filosofov, V. P.: Application of geomorphic methods in structural investigations, chap. Maps of isobases and residual relief, 43-52, NEDRA, Moskow, 1970 (in Russian).

Filosofov, V. P.: The basis of morphometric method in search of tectonic structures, Saratov, Saratov Univ. Publ. House., 1975 (in Russian).

FISRWG: Stream Corridor Restoration: Principles, Processes, and Practices, By the Federal Interagency Stream Restoration Working Group (15 Federal agencies of the US gov't), gPO Item No. 0120-A; SuDocs No. A 57.6/2:EN 3/PT.653. ISBN-0934213-59-3., 1998.

Goés, A. M.: A Formação Poti (Carbonífero Inferior) da Bacia do Parnaíba, Ph.D. thesis, Instituto de Geociências, Universidade de São Paulo, São Paulo., 1995.

Golts, S. and Rosenthal, E.: Morphotectonic Methods To Infer Groundwater Flow Under Conditions Of Scarce Hydrogeological Data-The Case Of Northern Arava, Israel, Hydrogeol. J., 1, 5-19, doi:10.1007/s100400050245, 1992.

Golts, S. and Rosenthal, E.: A morphotectonic map of the northern Arava in Israel, derived from isobase lines, Geomorphology, 7, 305-315, doi:10.1016/0169-555X(93)90060-F, 1993.

GRASS Development Team: Geographic Resources Analysis Sup- port System (GRASS GIS) Software, Version 6.4.0, http://grass osgeo.org, last access: 5 January 2010, 2009.

Grimaldi, S., Nardi, F., Di Benedetto, F., Istanbulluoglu, E., and bras, R. L.: A physically based method for removing pits in digital elevation models, Adv. Water Resour., 30, 2151-2158, doi:10.1016/j.advwatres.2006.11.016, 2007.

Grimaldi, S., Petroselli, A., Alonso, G., and Nardi, F.: Flow time estimation with variable velocity in ungauged basins, Adv. Water Resour., 33, 1216-1223, 10.1016/j.advwatres.2010.06.003, 2010.

Grohmann, C. H.: Morphometric analysis in Geographic Information Systems: applications of free software GRASS and R, Comput. Geosci., 30, 1055-1067, doi:10.1016/j.cageo.2004.08.002, 2004.

Grohmann, C. H., Riccomini, C., and Alves, F. M.: SRTMbased morphotectonic analysis of the Poços de Caldas Alkaline Massif, southeastern Brazil, Comput. Geosci., 33, 10-19, doi:10.1016/j.cageo.2006.05.002, 2007.

Hack, J. T.: Interpretation of erosional topography in humid temperate regions, Am. J. Sci., 258-A, 80-97, 1960.

Hack, J. T.: Stream-profile analysis and stream-gradient index, US Geological Survey, J. Res., 1, 421-429, 1973.

Hiruma, S. T. and Riccomini, C.: Análise morfométrica em neotectônica: o exemplo do Planalto de Campos do Jordão, SP, Revista do Instituto Geológico, 20, 5-19, 1999.

Hofierka, J., Mitasova, H., Parajka, J., and Mitas, L.: Multivariate interpolation of precipitation using Regularized Spline with Tension, Transactions in GIS, 6, 135-150, 2002.

Holmgren, P.: Multiple flow direction algorithms for runoff modelling in grid based elevation models: An empirical evaluation, Hydrol. Process., 8, 327-334, doi:10.1002/hyp.3360080405, 1994.

Horton, R. E.: Erosional development of streams and their drainage basins: hydrophysical approach to quantitative morphology, Geol. Soc. Am. Bull., 56, 275-370, 1945.

Jaboyedoff, M., Baillifard, F., Couture, R., Locat, J., and Locat, P.: Toward preliminary hazard assessment using DEM topographic analysis and simple mechanic modeling, in: Landslides Evaluation and stabilization, edited by: Lacerda, W. A., Ehrlich, M., Fontoura, A. B., and Sayo, A., 191-197, Balkema, 2004.

Jaboyedoff, M., Couture, R., and Locat, P.: Structural analysis of Turtle Mountain (Alberta) using digital elevation model: Toward a progressive failure, Geomorphology, 103, 5-16, doi:10.1016/j.geomorph.2008.04.012, 2009.

Kegel, W.: Lineament-tektonik in Nordwest-Brasilien, Geol. Rundsch., 54, 1240-1260, 1965.

Kinner, D., Mitasova, H., Harmon, R., Toma, L., and Stallard, R.: The Rio Chagres: A Multidisciplinary Profile of a Tropical Watershed, chap. GIS-based Stream Network Analysis for The Chagres River Basin, Republic of Panama, 83-95, Springer/Kluwer, 2005.

Leverington, D. W., Teller, J. T., and Mann, J. D.: A GIS method for reconstruction of late Quaternary landscapes from isobase data and modern topography, Comput. Geosci., 28, 631-639, 2002.

Louis, H.: Der Reliefsockel als Gestaltungsmerkmal des Abtragungsreliefs, Stuttgarter Geographische Studien, 69, 65-70, 1957.

Mackin, J. H.: Concept of graded river, Bull. Geol. Soc. Am., 59, 463-512, 1948. 
Marzoli, A., Renne, P. R., Piccirillo, E. M., Ernesto, M., Bellieni, G., and De Min, A.: Extensive 200-Million-Year-Old Continental Flood Basalts of the Central Atlantic Magmatic Province, Science, 284, 616-618, doi:10.1126/science.284.5414.616, 1999.

Meis, M. R. M., Miranda, L. H. G., and Fernandes, N. F.: Desnivelamentos de altitude como parâmetros para a compartimentação de relevo: bacia do médio-baixo Paraíba do Sul, in: Congresso Brasileiro de Geologia, XXXII, Salvador, SBG/BA, Anais, 4, 1489-1503, 1982.

Mitas, L. and Mitasova, H.: Spatial Interpolation, in: Geographical Information Systems: Principles, Techniques, Management and Applications, edited by: Longley, P., Goodchild, M. F., Maguire, D. J., and Rhind, D. W., Wiley, 481-492, 1999.

Mitasova, H. and Mitas, L.: Interpolation by regularized spline with tension:I Theory and implementation, Math. Geol., 25, 641-655, doi:10.1007/BF00893171, 1993

Modenesi-Gauttieri, M. C., Hiruma, S. T., and Riccomini, C.: Morphotectonics of a high plateau on the northwestern flank of the Continental Rift of southeastern Brazil, Geomorphology, 43, 257-271, doi:10.1016/S0169-555X(01)00137-4, 2002.

Nardi, F., Grimaldi, S., Santini, M., Petroselli, A., and Ubertini, 1.: Hydrogeomorphic properties of simulated drainage patterns using digital elevation models: the flat area issue, Hydrolog. Sci. J., 53, 1176-1193, doi:10.1623/hysj.53.6.1176, 2008.

Neteler, M. and Mitasova, H.: Open Source GIS : A GRASS GIS Approach, Third Edition (The International Series in Engineering and Computer Science), Vol. 773, Springer, New York, 2008.

Orlandini, S., Moretti, G., Franchini, M., Aldighieri, B., and Testa, B.: Path-based methods for the determination of nondispersive drainage directions in grid-based digital elevation models, Water Resour. Res., 39, 1144, doi:10.1029/2002WR001639, 2003.

Pannekoek, A. F.: Generalized contour maps, summit level maps and streamline surface mapas as geomorphological tools, Z. Geomorphol., 11, 169-182, 1967.

Penck, W.: Morphological analysis of landforms: a contribution to physical geology, (translated by Czech, H. and Boswell, K. C.), Macmillian, London, 1953.

Petersohn, E.: Nona rodada de licitações - Bacia do Parnaíba.[Brazil Round 9 - Parnaíba Basin], Agência Nacional de Petróleo, Gás Natural e Biocombustíveis [Brazilian National Agency of Petroleum, Natural Gas and Biofuels], (available at: http://www.anp.gov.br/brnd/round9/round9/palestras/Parnaiba\% 20(ingl\%C3\%AAs).pdf), last access: 3 February 2010, 2007.

Powell, J. W.: Exploration of the Colorado River of the West and its tributaries. Explored in 1869, 1870, 1871, and 1872 under the direction of the secretary of the Smithsonian Institution, Government Printing Office, Washington, 1875.

Quirk, D. G.: Base profile: a unifying concept in alluvial sequence stratigraphy, in: High Resolution Sequence Stratigraphy: Innovations and Applications, edited by: Howell, J. A. and Aitken, J. F., 104, 37-49, Geol. Soc. Sp., 1996.
Ribeiro, A. C., Lima, F. C. T., Riccomini, C., and Menezes, N. A.: Fishes of the Atlantic Rainforest of Boracéia: testimonies of the Quaternary fault reactivation within a Neoproterozoic tectonic province in Southastern Brazil, Ichthyol. Explor. Fres., 17, 157164, 2006.

Riccomini, C. and Assumpção, M.: Quaternary tectonics in Brazil, Episodes, 22, 221-225, 1999.

Sant'Anna, L. G., Schorscher, H. D., and Riccomini, C.: Cenozoic tectonics of the Fonseca Basin region, eastern Quadrilátero Ferrífero, MG, Brazil, J. S. Am. Earth Sci., 10, 275-284, 1997.

Schobbenhaus, C. and Bellizzia, A.: Geological Map of South America, 1:5 000000 (coord.), CGMW, CPRM, DNPM, Unesco, Brasília, 2001.

Schobbenhaus, C., Campos, D. A., Derze, G. R., and Asmus, H. E.: Mapa geológico do Brasil e da área oceânica adjacente incluindo depósitos minerais. Escala 1:2500 000 (Geological map of Brazil and adjacent oceanic area, including mineral deposits. 1:2 500000 scale), DNPM, Brasília., 1984.

Sklar, L. and Dietrich, W.: Rivers over rock: fluvial processes in bedrock channels, Geophysical Monograph, Vol. 107, Chap. River longitudinal profiles and bedrock incision models: Stream power and the influence of sediment supply, 237-260, American Geophysical Union, 1998.

Smith, M. and Wise, S.: Problems of bias in mapping linear landforms from satellite imagery, Int. J. Appl. Earth Obs., 9, 65-78, doi:10.1016/j.jag.2006.07.002, 2007.

Stewart, I. and Hancock, P.: What is a fault scarp?, Episodes, 61, 256-263, 1990.

Strahler, A. N.: Hypsometric (area-altitude) analysis of erosional topography, B. Geol. Soc. Am., 63, 1117-1142, 1952.

Tarboton, D. G. and Bras, R. L.: On the extraction of channel networks from digital elevation data, Hydrol. Process., 5, 81-100, 1991.

Tricart, J. and Cailleux, A.: Cours de Geomorphologie I: Geomorphologie Structurale, C. D. U. Paris, 0, 252, 1957.

Yilmaz, H. M.: The effect of interpolation methods in surface definition: an experimental study, Earth Surf. Proc. Land., 32, 13461361, 2007.

Yue, T. X., Du, Z. P., Song, D. J., and Gong, Y.: A new method of surface modeling and its application to DEM construction, Geomorphology, 91, 161-172, 2007.

Zuchiewicz, W.: Selected geomorphic method applied to neotectonic studies in the Northern Carpathians, Bulletin de 1'Association française pour l'étude du quaternaire, 26, 131-136, 1989.

Zuchiewicz, W. and Oaks, R.: Geomorphology and structure of the Bear River Range, north eastern Utah: a morphometric approach, Z. Geomorphol., Suppl.-Bd. 94, 41-55, 1993. 